\title{
$\mathrm{AC}$ 회생이 가능한 배터리 충 · 방전 테스트 시스템
}

\author{
김준구 ${ }^{1}$, 윤선재 ${ }^{2}$, 김재형 ${ }^{3}$, 원 충연 $^{\dagger}$, 나종국 $^{4}$
}

\section{AC Regeneratable Battery Charging and Discharging Test System}

\author{
Jun-Gu Kim ${ }^{1}$, Sun-Jae Youn ${ }^{2}$, Jae-Hyung $\mathrm{Kim}^{3}$, Chung-Yuen Won ${ }^{\dagger}$, Jong-Kuk Na ${ }^{4}$
}

\begin{abstract}
In this paper, $15[\mathrm{~kW}] \mathrm{AC}$ regenerative system for battery charging and discharging test is proposed. The regenerative system is able to regenerate surplus energy to the grid in discharging mode, and the inverter of the system can be operated as a converter to compensate scarce energy in charging mode. In case of the conventional DC charging and discharging system, the regenerative energy is consumed by a resistor. However, as the proposed system regenerates the surplus energy to the grid through using $\mathrm{DC}-\mathrm{AC}$ inverter, the energy saving effect can be achieved. In this paper, $15[\mathrm{~kW}]$ battery charging and discharging system is developed, and the validity of the system is verified through simulation and experimental results.
\end{abstract}

Keywords : AC regeneration system, Battery charging and discharging, Grid connected

\section{1. 서 론}

최근 자동차 산업 분야는 연비 향상을 목적으로 하는 저공해 차량과 도심에서 환경 물질 배출의 최소화를 목 적으로 무공해 차량 (Zero Emission Vehicle)에 대한 연 구가 진행 중이고, 종류로는 일부 또는 전부의 추진동력 을 전기에너지로 사용하는 $\mathrm{HEV}$ (Hybrid Electric Vehicle), PHEV (Plug-in HEV) EV(Electric Vehicle) 및 $\mathrm{FCEV}(\mathrm{Fuel}$ Cell EV)가 있다. 전기에너지를 사용하 는 친환경 전기 자동차인 $\mathrm{PHEV}$ 나 $\mathrm{EV}$ 의 도입은 전기에 너지의 측면에서는 큰 패러다임의 변화이며, 자동차 산 업은 물론이고 관련 부품 산업과 전력 산업 전반에 걸 쳐 많은 변화가 예상된다 ${ }^{[1]}$.

친환경 자동차와 더불어 소형의 리튬 2 차 전지시장은 모바일 IT산업의 성장에 힘입어 꾸준하게 성장해 왔다. 최근 디지털 컨버젼스로 대변되는 디지털 기기간의 융.

Paper number : TKPE-2012-17-2-2

ISSN : 1229-2214

† Corresponding Author : woncy@skku.edu, College of Information and Communication Engineering, Sungkyunkwan University

Tel : +82-31-290-7115 Fax : +82-31-290-7179

${ }_{2}^{1}$ School of Photovoltaic System Engineering, Sunkyunkwan University

${ }^{2}$ Dept. of Mobile Communications Engineering,

Sunkyunkwan University

${ }^{3}$ Senior Research Engineer Robot Technology Group,

Samsungtechwin

${ }^{4}$ KapJin Co.

Manuscript received Oct. 6, 2011; accepted Dec. 19, 2011

- 본 논문은 2011년 전력전자학술대회 외부장학금 수혜논문임
복합 추세에 따라 휴대폰 전원으로 사용되는 2차 전지 의 수명 및 용량에 대한 요구가 커지고 있으며, 특히 스 마트폰 등 신 IT 휴대용 전자기기의 수요증가는 이러한 요구를 더욱 확대 시키고 있다. 따라서 국내 전지 개발 기업들은 기술 발전에 많은 투자를 하고 있으며, 보유한 기술력과 제품을 바탕으로 국내 및 국외의 시장 점유율 을 확대해 나가고 있다.

그림 1 과 같이 2 차 전지의 사용 증가와 더불어 이와 관련된 배터리 및 BMS(Battery Management System), 충-방전기 등에 대한 연구가 중요한 이슈로 대두되고 있다. 특히 위의 과제를 풀어가기 위해서는 2 차 전지에 대한 신뢰성이 검증되어야 한다. 이러한 이유로 배터리

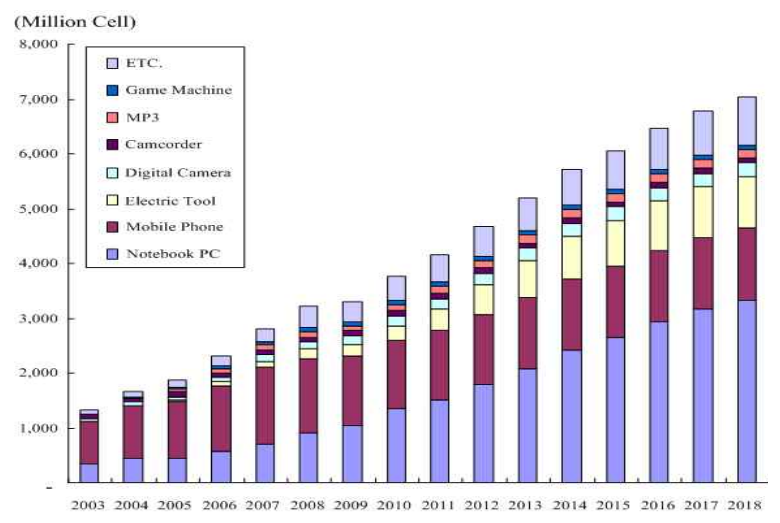

Fig. 1 The market size trends and prospects according to the needs of small lithium-ion battery 


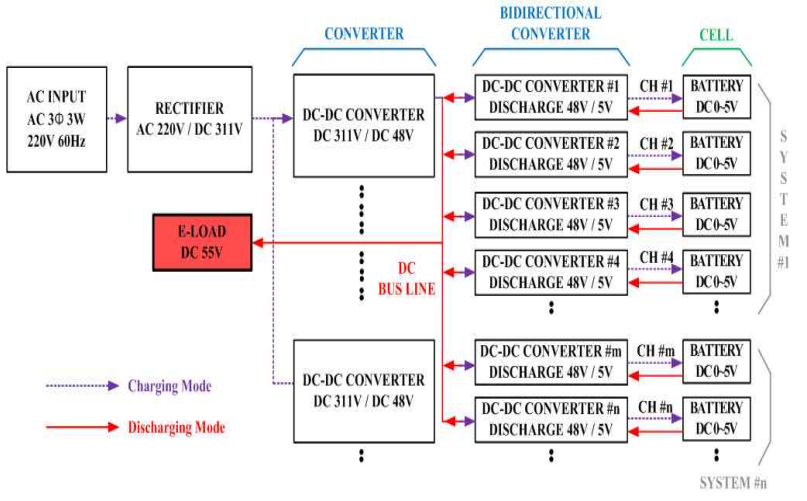

Fig. 2 The block diagram of a DC regenerative system

에 대한 정확한 데이터 제공 및 사용자의 요구에 유연 한 시스템이 절실히 필요하게 되었다.

그림 2 는 기존의 $\mathrm{DC}$ 회생 시스템의 블록도이다. 배터 리 충전 시 3상 다이오드 정류기와 $\mathrm{DC}-\mathrm{DC}$ 컨버터를 통하여 DC-BUS Line을 48[V]로 제어한다. 48[V]는 양 방향 컨버터를 통하여 배터리 충전 전압인 $5[\mathrm{~V}]$ 를 유지 하게 된다. 기존의 $\mathrm{DC}$ 회생 시스템에서는 배터리 충전 시 계통의 전력을 다이오드 정류기를 이용하여 충전 전 력을 수급하였고 방전 시에는 전자부하(저항)를 이용하 여 열로 소비시켰다. 잉여 전력을 사용하지 않고 소비하 였기 때문에 전력 활용률 및 효율이 낮다 ${ }^{[2]}$. 그리고 배 터리 방전 시, 48[V]로 유지하던 DC-BUS Line은 방전 에너지를 소비할 패스가 없기 때문에 계속적으로 상승 하게 된다. 여러 시스템이 연결되어 테스트가 되는 경 우, 방전 동작중인 시스템의 에너지는 다른 시스템의 충 전 에너지로 사용되어 약간의 $\mathrm{DC}$ 회생을 하게 된다. 하 지만 방전모드로 테스트 중인 시스템보다 충전 모드로 테스트 중인 시스템이 현저히 적은 경우에는 $\mathrm{DC}-\mathrm{BUS}$ Line을 상승시키게 된다. 기존의 시스템은 $\mathrm{DC}-\mathrm{BUS}$ Line이 52[V] 이상으로 상승하는 경우, 시스템 보호를 위해 병렬로 연결된 전자 부하(저항)를 통하여 열로 소 비한다. 기존의 $\mathrm{DC}$ 충 - 방전 테스트 시스템은 장시간 테스트가 이루어져야 하는 만큼 전자 부하를 통하여 발 생한 열에 대한 추가적인 대책이 필요하다. 이러한 문제 를 해결하기 위하여 냉각 시스템을 따로 추가하였지만 제품의 가격 및 크기가 커지는 문제점이 발생한다. 또한 잉여 전력을 저항을 통하여 소비하기 때문에 전력 사용 률이 낮아 시스템 전체 효율을 떨어뜨리게 된다.

본 논문에서는 배터리의 충 - 방전 시, 방전 모드에서 잉여 전력을 3상 계통에 회생할 수 있는 $\mathrm{AC}$ 회생 시스 템을 제안하였다. 제안하는 $\mathrm{AC}$ 회생 시스템에서는 배 터리에 충전된 $\mathrm{DC}$ 전압을 방전 시에 $\mathrm{AC}$ 전압으로 변 환하여 계통으로 회생하여 준다.

\section{2. 제안하는 $A C$ 회생 시스템}

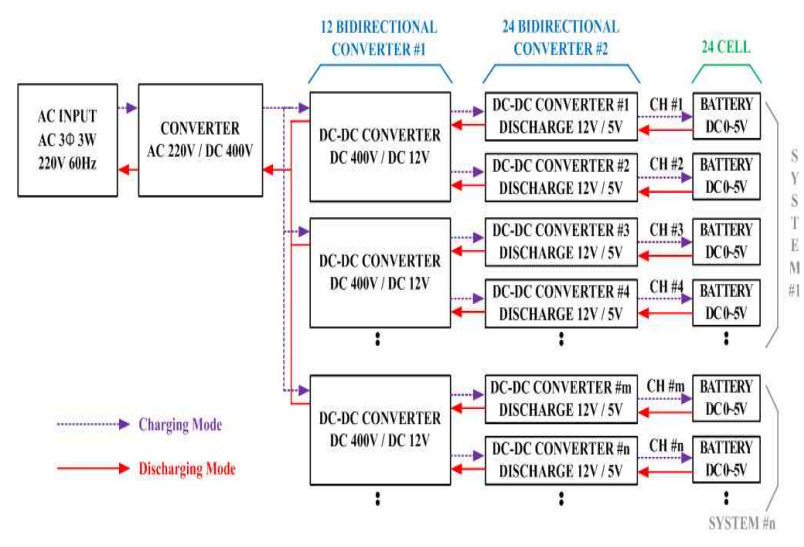

Fig. 3 The block diagram of an AC regenerative system

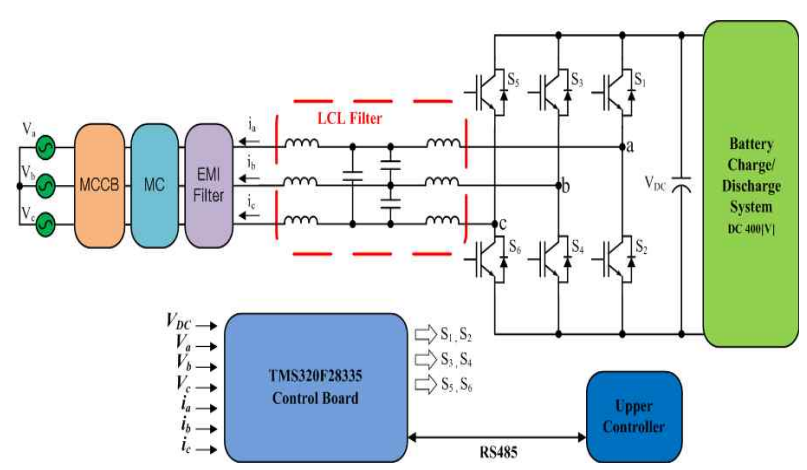

Fig. 4 The block diagram of a grid-connected DC-AC inverter

\section{$2.1 \mathrm{AC}$ 회생 시스템}

그림 3은 제안하는 계통 연계형 $\mathrm{AC}$ 회생 시스템의 블록도이다. 배터리 방전 시 두 개의 양방향 컨버터를 통하여 승압된 DC-Link를 $\mathrm{DC}-\mathrm{AC}$ 인버터를 통하여 계 통으로 회생한다. 기존의 $\mathrm{DC}$ 회생 시스템에서 다이오드 로 구성한 정류부를 스위치로 바꾸어서 양방향 컨버터 로 동작이 가능하도록 하였다. PWM 제어를 통하여 더 높은 승-강압 비를 얻을 수 있다. 배터리 충전 시에는 $\mathrm{PWM}$ 인버터를 $\mathrm{AC}-\mathrm{DC}$ 컨버터로 동작시켜 $\mathrm{DC}-\mathrm{Link}$ 확보가 가능하다. 이를 통하여 기존의 시스템과 크기 변 화 없이 충-방전 활용이 가능하기 때문에 불필요한 시 스템의 축소 및 안정적인 동작이 가능하다. 또한 $\mathrm{DC}$ 회 생 시스템에서 전자 부하로 소진하는 잉여 전력을 계통 으로 회생하기 때문에 에너지 활용률이 높고, 추가적인 전자 부하 및 냉각 시스템이 필요하지 않는다.

\section{2 계통 연계형 인버터}

그림 4 는 3 상 계통 연계형 $\mathrm{DC}-\mathrm{AC}$ 인버터의 구조이 다. 제안한 시스템에서 사용한 LCL 필터는 각 인덕터의 허용 전류 리플을 설정하여 인덕턴스를 구하고, 무효 전 력의 제한값을 이용하여 커패시터를 설계한다 ${ }^{[3]}$. LCL 필터는 기존의 $\mathrm{L}, \mathrm{LC}$ 필터에 비해 효과적인 필터링이 가능하여 전체 시스템의 크기 및 단가를 절감시킬 수 


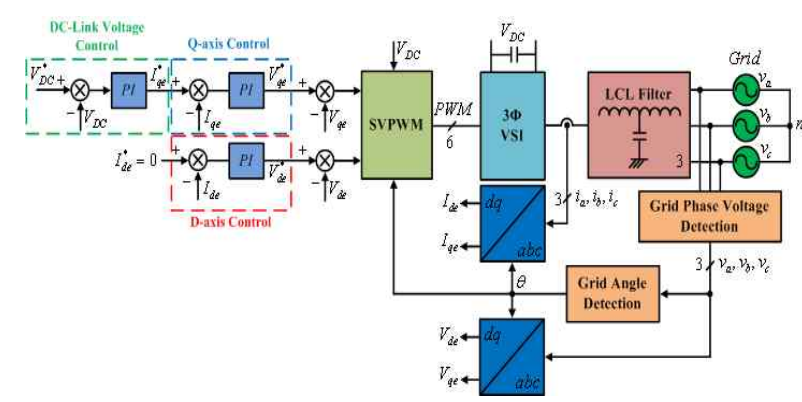

Fig. 5 Block diagram of a grid-connected DC-AC inverter controller

있지만 공진 주파수에서의 고조파가 증폭되는 문제점이 있다. 이러한 문제를 해결하기 위해서 커패시터에 저항 을 직렬로 삽입하여 공진을 억제하는 패시브 댐핑 기법 을 적용하였다. TI社의 TMS320F28335를 사용하여 제어 하고, $\mathrm{DC}-\mathrm{Link}$ 전압과 3 상 $\mathrm{AC}$ 전압 및 전류를 측정하 여 연산한다. 또한 다수의 테스트 장비가 동시에 운전되 기 때문에 원활한 동작을 위해서 상위 제어기와 RS485 통신을 사용한다.

그림 5는 3상 계통 연계형 인버터의 제어 블록도를 나타낸다. 제안한 논문에서 사용한 동기좌표계를 PLL 방법은 3상 전원을 $\mathrm{d}-\mathrm{q}$ 변환을 통해서 동기좌표계로 변 환하여 전원각 제어를 하는 방법이다 ${ }^{[4-5]}$. 하지만 불평형 발생 시, d축과 $\mathrm{q}$ 축에서 계통 주파수의 2 배에 해당하는 리플이 발생하게 되어 정확한 위상각을 검출하는데 어 려움이 발생한다. 이를 해결하기 위해 불평형 사고에서 도 정상분 전압은 항상 평형을 유지하기 때문에 정상분 전압을 계산을 통해 추출하여 PLL을 검출한다 ${ }^{[6-8]}$. 또한 측정된 DC-Link 전압은 지령전압과 비교하여 오차만큼 전류지령을 생성한다. 이 때, 오차 성분에 대한 완전한 제거를 위하여 PI제어기를 사용하였다. 식 (1)과 (2)는 전향보상이 추가된 동기 좌표계에서의 $\mathrm{d}-\mathrm{q}$ 전압방정식 을 나타낸다. 전향보상은 전압제어를 위해 $\mathrm{DC}$ 단으로 흘 러야 할 전류와 부하 측으로 흘러야 할 전류를 계산하 여 입력측에 흐르도록 함으로써, 부하 변동에 대한 영향 을 최소화하여 과도응답 및 정상상태응답을 향상시키는 효과가 있다. 실제로 사용되는 유효전력은 $\mathrm{q}$ 축 전류 성 분에 의해서만 제어되기 때문에 전압 제어기의 출력은 $\mathrm{q}$ 축 전류의 지령값이 되고 식(3)과 같다.

$$
\begin{aligned}
& V_{d}^{e}=L_{i} \frac{d i_{d}^{e}}{d t}-\omega L_{i} i_{q}^{e}+e_{d}^{e} \\
& V_{q}^{e}=L_{i} \frac{d i_{q}^{e}}{d t}-\omega L_{i} i_{d}^{e}+e_{q}^{e} \\
& i_{q}^{e^{*}}=K_{p-V d c}\left(V_{d c}^{*}-V_{d c}\right)+K_{i-V d c} \int\left(V_{d c}^{*}-V_{d c}\right)
\end{aligned}
$$

일반적인 공간벡터 전압변조방식(SVPWM)은 벡터 공 간상의 위치에 기준을 두어 스위칭 시간을 결정하기 때

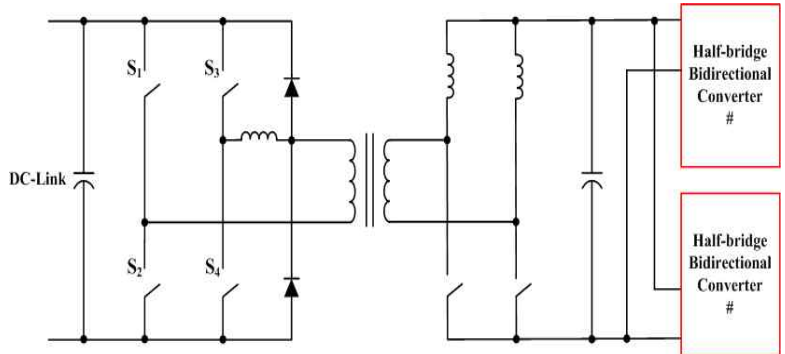

Fig. 6 Bidirectional converter combined full-bridge with two inductor method

문에 연산이 복잡하고, 수행시간이 길다. 이러한 단점을 보완하기 위해 SVPWM의 복잡한 계산이 필요 없이 3 상 기준 전압에 계산된 Offset 전압을 더하여 Sinusoidal $\mathrm{PWM}$ 을 적용한 $\mathrm{Min}-\mathrm{max}$ 방식을 사용하였다. 이 Offset 전압은 실제로 출력되는 상전압에는 영향을 미치 지 않는다 ${ }^{[9-10]}$.

\section{3 제안하는 양방향 컨버터}

그림 6은 Full-bridge 컨버터와 Two-inductor 컨버터 를 결합한 양방향 컨버터이다. 강압 모드로 동작할 경 우, Full-bridge 방식의 컨버터는 400[V]의 DC-Link 전 압을 $12[\mathrm{~V}]$ 로 출력한다. Full-bridge 방식의 컨버터는 위 상 천이 방식을 사용하여 제어하기 때문에 소프트 스위 칭이 가능하고, 트랜스 2 차 측의 승압 스위치를 동기 정 류 방식으로 제어한다. 승압 모드로 동작할 경우, Two-inductor 방식의 컨버터는 배터리 방전 시 Half-bridge 방식의 양방향 컨버터에서 승압된 12[V] 전 압을 400[V]로 승압하게 된다. Two-inductor 방식은 듀 티를 $50 \%$ 이상으로 동작시켜 각각의 인덕터에 에너지를 저장 할 수 있는 구간을 필요로 한다.

\section{3. 시스템 설계 및 제작}

\section{1 배터리 충 - 방전 테스트 장치}

표 1은 70[A] 24채널의 시스템 파라미터를 나타낸다. $220[\mathrm{Vrms}] 3$ 상 3 선식이고 $15[\mathrm{~kW}$ 출력이 가능하다. 배 터리 전압 및 전류 센싱에 16 [bit] $\mathrm{AD}$ 를 사용하기 때문 에 충·방전 정밀도가 높다.

그림 7은 배터리 충 - 방전 테스트 장치를 나타낸다. 테스트 장치는 개별의 배터리를 충전과 방전을 할 수 있는 12 개의 모듈로 구성되어 있고, 하나의 모듈은 그림 6 과 같이 2 개의 배터리를 충 - 방전 할 수 있도록 구성 되어 있다. 제품 뒷면의 $\mathrm{DC}-\mathrm{Link}$ 단을 이용하여 각각의 모듈로 전력이 전달된다. 또한 시스템 초기 설치 시, 계 통 입력단자에 $\mathrm{R}-\mathrm{S}-\mathrm{T}$ 의 상순이 아닌 역상 $(\mathrm{R}-\mathrm{T}-\mathrm{S})$ 으로 결선이 되면 전원단의 이상으로 판단하여 시스템의 동 작을 정지한다. 하나의 시스템에는 24 개의 배터리를 테 스트 할 수 있지만, 상위 제어기와의 통신을 통하여 시 
Table 1 Parameters of $\mathrm{AC}$ regenerative system

\begin{tabular}{|c|c|c|c|c|c|c|}
\hline \multicolumn{2}{|c|}{$\begin{array}{l}\text { Parameter } \\
\end{array}$} & $\begin{array}{ll}\text { Value } \\
\end{array}$ & Unit & Parameter & Value & Unit \\
\hline \multicolumn{2}{|c|}{ Power } & 15 & [kW] & $\begin{array}{l}\text { AC Rated } \\
\text { Voltage }\end{array}$ & $220 \pm 13$ & [Vrms] \\
\hline \multicolumn{2}{|c|}{ DC-Link } & 400 & {$[\mathrm{~V}]$} & $\begin{array}{c}\text { AC Rated } \\
\text { Current }\end{array}$ & 39.36 & [Arms] \\
\hline \multicolumn{2}{|c|}{ DC-Bus } & 12 & {$[\mathrm{~V}]$} & $\begin{array}{c}\mathrm{AC} \\
\text { Frequency }\end{array}$ & 60 & {$[\mathrm{~Hz}]$} \\
\hline \multirow{3}{*}{$\begin{array}{c}\mathrm{B} \\
\mathrm{a} \\
\mathrm{t} \\
\mathrm{t} \\
\mathrm{e} \\
\mathrm{r} \\
\mathrm{y}\end{array}$} & \multicolumn{2}{|c|}{ Rating } & $3.7 \mathrm{~V} 40 \mathrm{Ah}$ & THD & $<<5$ & [\%] \\
\hline & \multicolumn{2}{|c|}{$\begin{array}{l}\text { Voltage } \\
\text { Range }\end{array}$} & $2.7 \mathrm{~V} \sim 4.2 \mathrm{~V}$ & Efficiency & $>95$ & {$[\%]$} \\
\hline & \multicolumn{2}{|c|}{ Type } & $\mathrm{Li}$-ion & P.F. & $>0.98$ & - \\
\hline
\end{tabular}

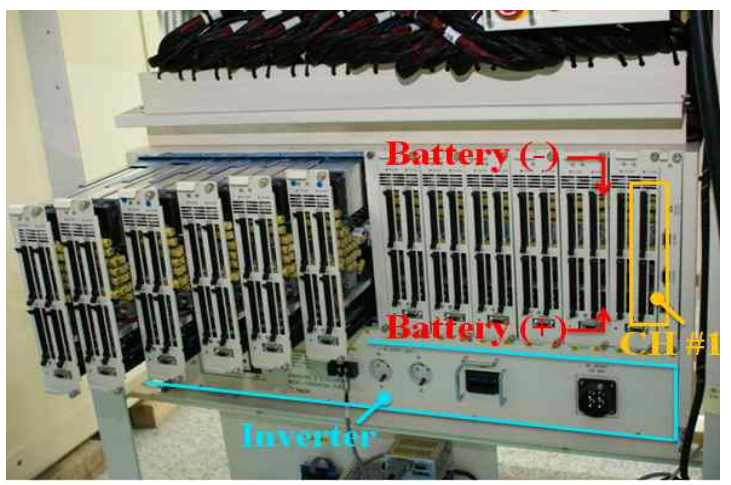

Fig. 7 The test set up of battery charging and discharging

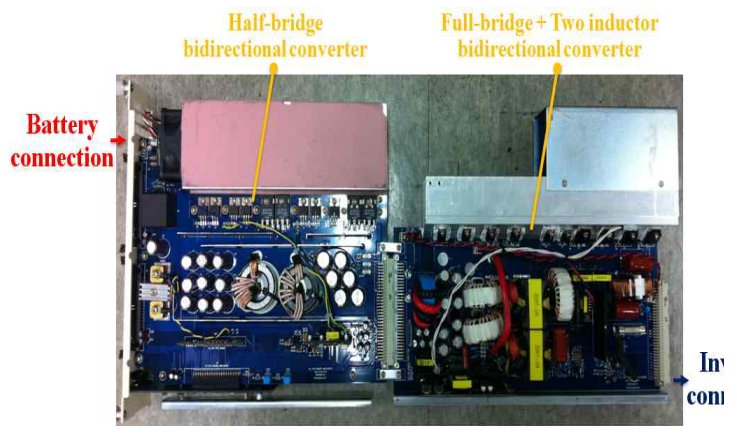

Fig. 8 The inner part composition of each module

스템 추가 테스트가 가능하다. 또한 모듈 형식이기 때문 에 고장 및 이상이 발생 할 경우, 점검 및 교체를 손쉽 게 할 수 있다.

\section{2 양방향 컨버터부}

그림 8은 양방향 $\mathrm{DC}-\mathrm{DC}$ 컨버터의 모듈 내부를 나타 낸다. 하나의 모듈은 그림 6과 같이 Full-bridge Type의 컨버터와 Two-Inductor Type의 컨버터를 결합하여 양 방으로 동작이 가능하다. 또한 결합된 양방향 컨버터의 저전압단은 Half-bridge Type 양방향 컨버터의 고전압 단과 연결된다. 그리고 Half-bridge Type 양방향 컨버 터 2개가 하나의 모듈을 구성하기 때문에 각 모듈별로 2 개의 배터리 충 - 방전 하게 된다. 또한 그림 8 의 Inverter connection은 그림 7의 뒤쪽에 있는 DC-Link 단자에 연결되어 다른 모듈과 결합된다.

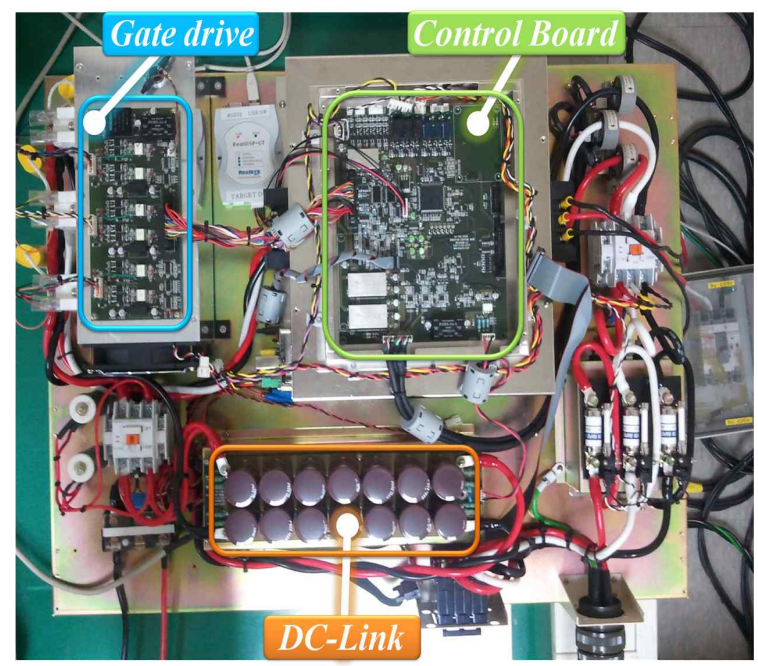

Fig. 9 The inverter part of the battery charging and discharging system

\section{3 인버터부}

그림 9는 배터리 충 - 방전 시스템에서 인버터부를 나 타낸다. 표 1 에서 나타낸 시스템의 효율을 고려하면 배 터리 충전 시, $12.8[\mathrm{~kW}]$ 의 전력이 계통으로부터 공급되 고, 배터리 방전 시, $5.5[\mathrm{~kW}]$ 의 전력이 계통으로 공급된 다. 제안하는 시스템의 인버터부는 배터리 충전 시 $12.8[\mathrm{~kW}]$ 의 전력전달이 가능해야 하기 때문에 시스템을 $15[\mathrm{~kW}]$ 로 설계하여 제작하였다.

\section{4. 시뮬레이션}

배터리 충 - 방전 시스템은 기존의 DC 회생 시스템에 서 저항으로 소비되던 에너지를 계통으로 회생하여 에 너지 활용률을 높이는 것이 중요하다. 그렇기 때문에 기 존의 시스템에서 추가된 인버터의 동작 특성은 인버터 및 컨버터 동작 시 응답특성이 빨라야 하며 가장 안정 적으로 동작해야 하는 부분이다. 제안하는 $\mathrm{AC}$ 회생 시 스템의 동작을 확인하기 위하여 PowerSIM사의 PSIM

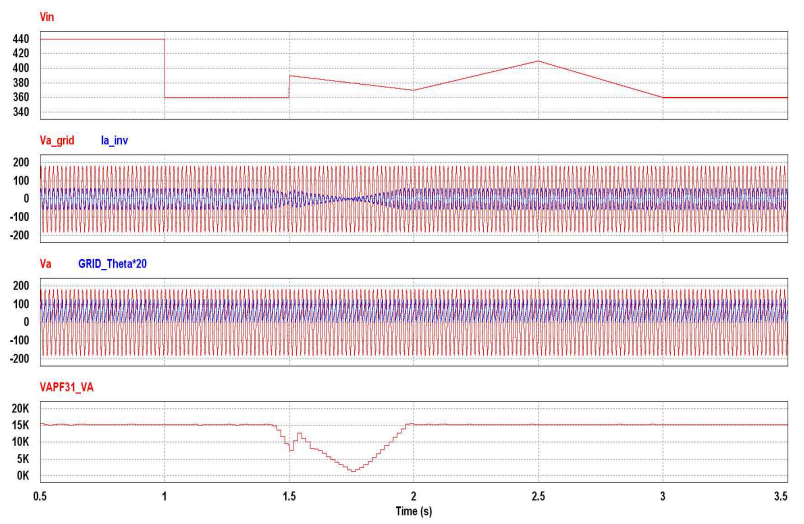

Fig. 10 The simulation results of inverter and converter with various DC-link 


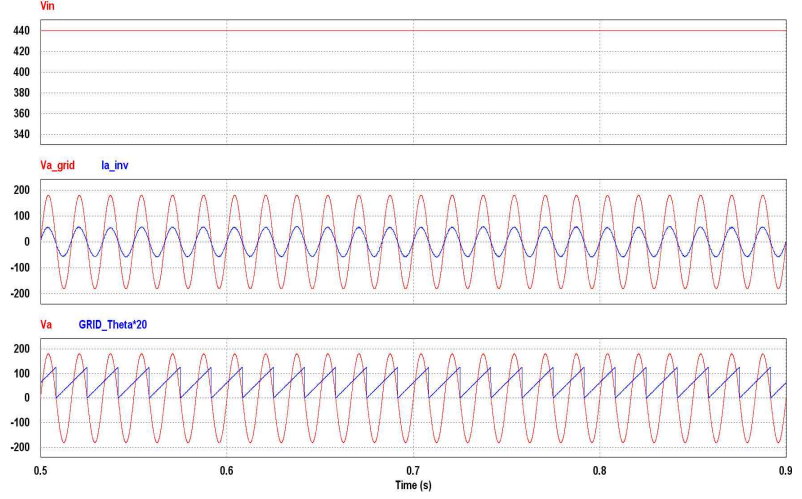

Fig. 11 The grid connected inverter waveform of inverter with increased DC-link

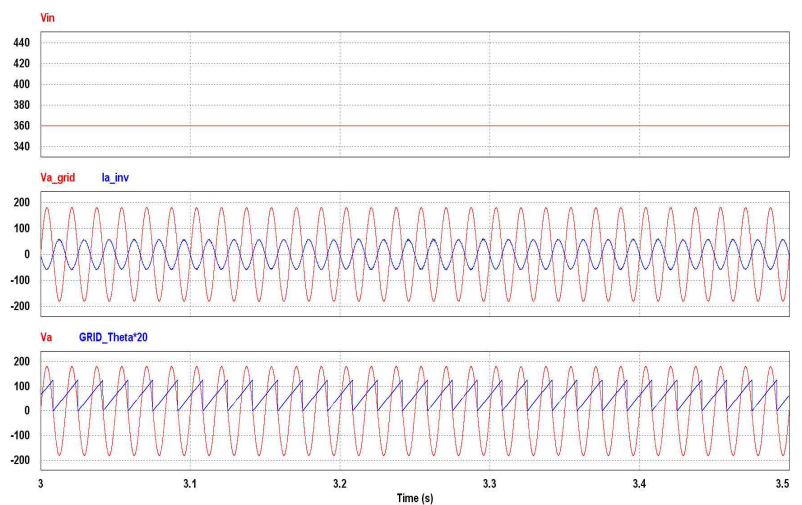

Fig. 12 The grid connected inverter waveform of inverter with decreased DC-link

6.0을 사용하여 시뮬레이션을 수행하였다. 배터리 충 - 방 전 시 $\mathrm{DC}-\mathrm{Link}$ 단의 전압 감소 및 상승하는 상황을 만들 어서 각 상황별 인버터의 동작을 시뮬레이션 하였다.

그림 10 은 DC-Link 가변에 따른 인버터의 동작을 나 타내는 파형이다. 그림 11 과 그림 12 는 인버터의 각 동 작 상황을 $\mathrm{DC}-\mathrm{Link}$ 전압에 따라 상전압과 상전류 그리 고 계통 전압으로부터 검출된 위상각을 나타낸다. 그림 11 과 같이 DC-Link단의 전압이 400[V]보다 큰 경우, 잉 여 에너지는 계통 전압과 동상으로 계통연계가 되는 것 을 확인 할 수 있다. 또한 그림 12 와 같이 DC-Link단 전압이 400[V]보다 낮은 경우, 인버터는 컨버터로 동작 하여 계통 전압과 역상의 전류가 흐르는 것을 확인 할 수 있다.

\section{5. 실험 결과}

본 논문에서 제안한 배터리 충 - 방전 시스템의 실험 은 $15[\mathrm{~kW}]$ 하드웨어를 제작하여 진행하였다. 그림 13 과 그림 14 는 계통연계시의 전압 및 전류를 나타내는 파형 이다. 그림 13 과 같이 3 상 $220[\mathrm{Vrms}]$ 의 선간 전압을 $\mathrm{DSP}$ 를 이용하여 센싱한다. 센싱된 선간접압을 그림 5 에 서와 같이 상전압을 검출하게 된다. 검출된 계통의 상전
압과 정상분을 계산하고, $\mathrm{DAC}$ 를 통하여 출력한 파형을 나타낸다. 그림 13을 통하여 계통의 선간전압과 $\mathrm{DAC}$ 로 출력한 정상분 상전압은 30 도 위상 차이가 나고, 정상분 상전압을 이용하여 $\mathrm{DAC}$ 로 출력한 위상이 일치되는 것 을 확인 할 수 있다. 또한 계통의 위상을 이용하여 그림 14 에서 나타낸 부분과 같이 계통의 전류와 위상이 동상 이다. 이것은 계통의 상전압과 동상인 상전류가 인버터 를 통하여 계통으로 출력되고 있음을 나타내고, 역률 $98 \%$ 이상을 만족한다.

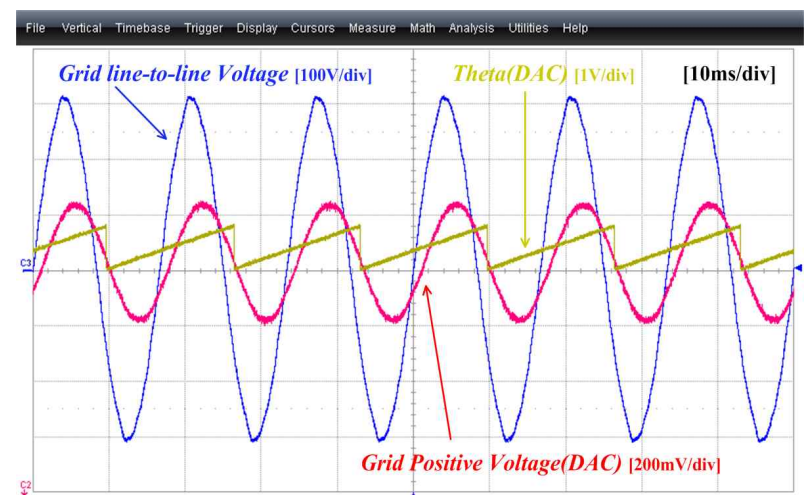

Fig. 13 The line-to-line voltage and phase detection waveforms of the grid

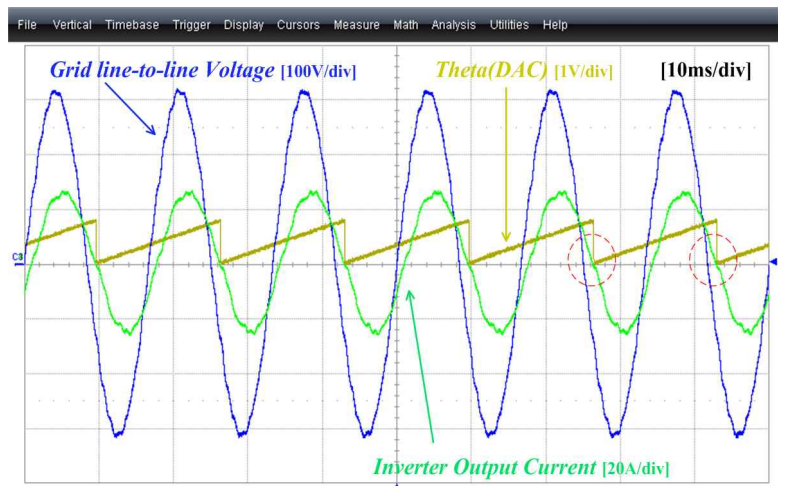

Fig. 14 The phase current waveforms of the inverter at grid-connected condition

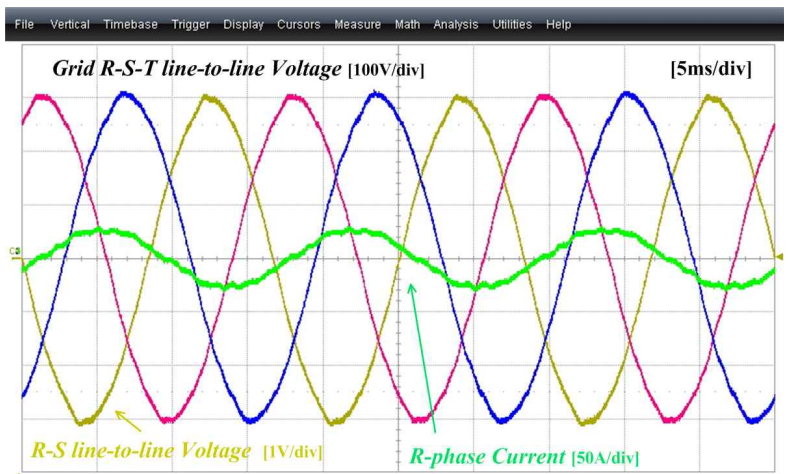

Fig. 15 The phase current waveforms at converter operation 


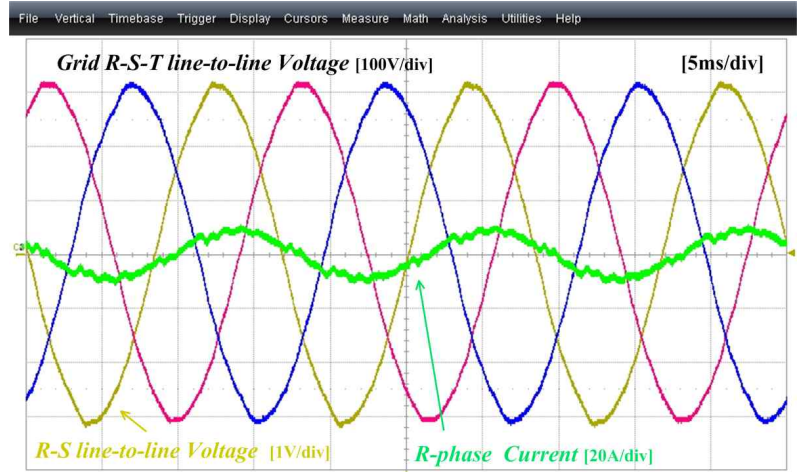

Fig. 16 The phase current waveforms at inverter operation

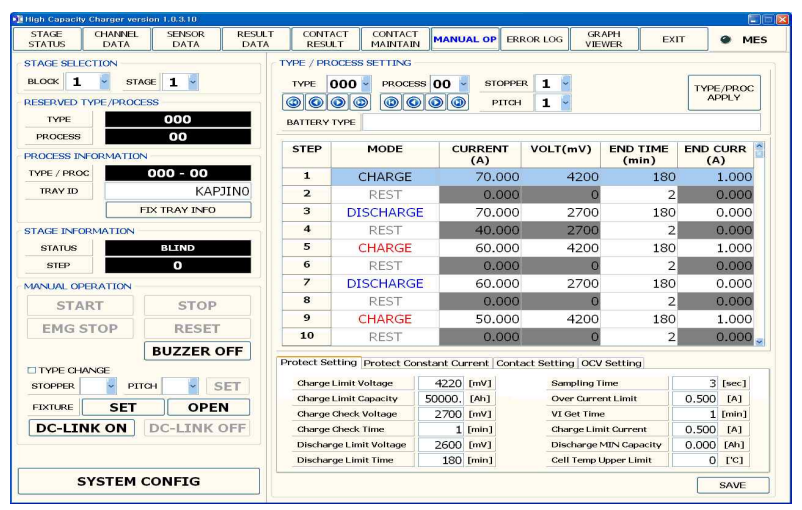

Fig. 17 The data collecting program of the battery charging and discharging system

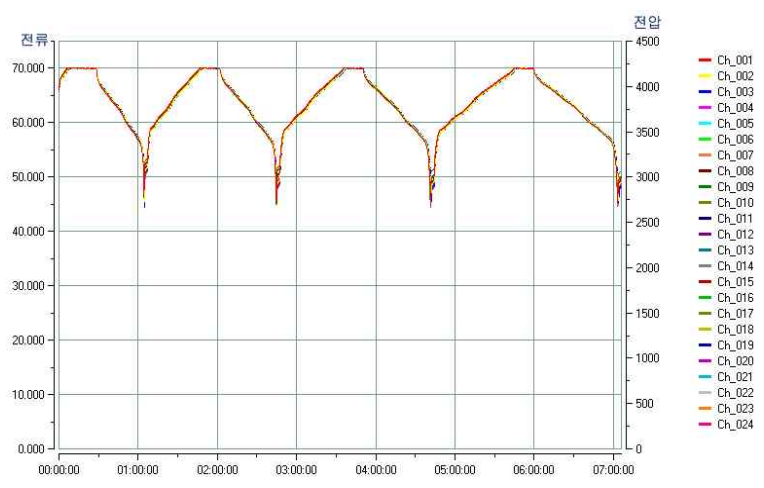

Fig. 18 The voltage variation graphs of 24 channels

그림 15 와 그림 16 은 계통의 $\mathrm{R}-\mathrm{S}, \mathrm{S}-\mathrm{T}, \mathrm{T}-\mathrm{R}$ 선간전 압과 $\mathrm{R}$ 상 전류에 대한 파형이다. 그림 15는 배터리를 충전 시, 인버터가 컨버터로 동작하는 파형으로 $\mathrm{R}-\mathrm{S}$ 의 선간전압과 $\mathrm{R}$ 상 전류파형이 위상은 30도 지연되어 있고, 역상의 전류가 흐르는 것을 확인 할 수 있다. 또한 그림 16 은 그림 15 와 반대로 $\mathrm{R}-\mathrm{S}$ 의 선간전압과 $\mathrm{R}$ 상 전류파 형이 위상은 30 도 지연되어 있고, 동상의 전류가 흐르는 것을 확인할 수 있다.

그림 17은 배터리 충 - 방전 테스트 시스템의 데이터 수집 프로그램을 나타낸다. 앞서 나타낸 것과 같이 배터

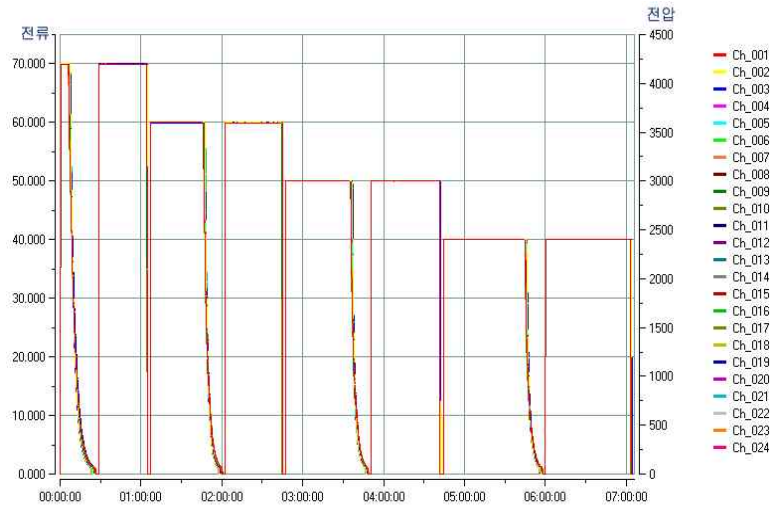

Fig. 19 The current variation graphs of 24 channels

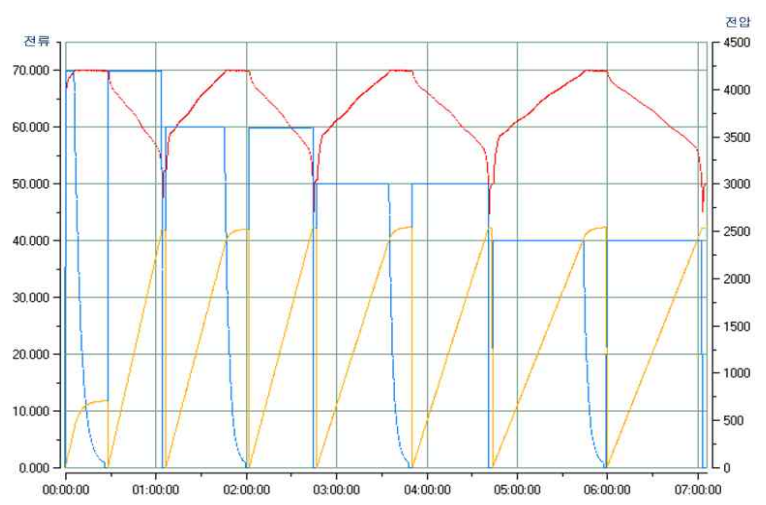

Fig. 20 The voltage, current and power variation graphs of a single channel

리의 충전 및 방전 전압은 짧은 시간에 나타낼 수 없기 때문에 오랜 시간 테스트를 진행하고, 각각의 전압 및 전류 데이터를 수집하여 파일로 저장하게 된다. 저장된 프로그램을 제작한 Viewer를 이용하여 나타내면 아래와 같다.

그림 18 과 그림 19 는 배터리 충 - 방전 시 24 개 채널 에 대하여 전압 및 전류를 모니터링한 그래프를 나타냈 다. 그림에서 왼쪽은 전류를 오른쪽은 전압을 나타낸다. 전압의 경우, $1 / 1000$ 로 전압을 환산하여 모니터링 한다. 24 개의 채널별 배터리는 동일한 충 - 방전 패턴으로 7 시 간동안 이루어 졌고, 연속적인 전압 및 전류 변화 그래 프를 확인 할 수 있다.

그림 20 은 위의 24 개 채널 중에서 하나의 채널을 전 압 및 전류 그리고 전력의 변화를 함께 나타냈다. 그 림 21는 그림 20을 확대한 그래프이다. 그림 21에서 나 타냈듯이 충전과 방전 그리고 $\mathrm{CV}$ 모드로 나눌 수 있다. 배터리 충전모드는 양방향 컨버터를 $50[\mathrm{~A}]$ 로 정전류 제 어한다. 이 때 배터리 전압은 계속적으로 상승하게 되 고, 이에 따라 전력도 상승한다. 배터리 전압이 계속적 으로 상승하다가 4.2[V]가 되면 $\mathrm{CV}$ 모드로 전환되고, 전류는 감소하는 것을 확인 할 수 있다. 배터리 방전모 드는 양방향 컨버터를 50[A]로 정전류 제어를 한다. 방 


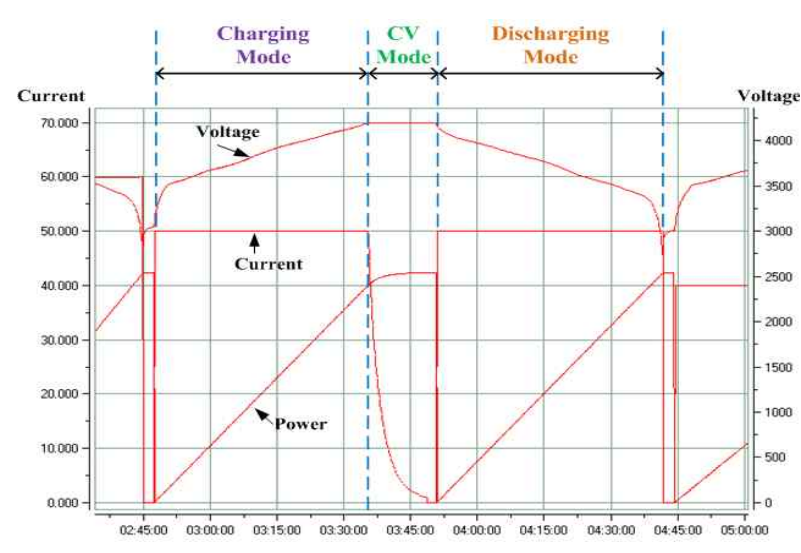

Fig. 21 The expended charging and discharging graphs of a single channel

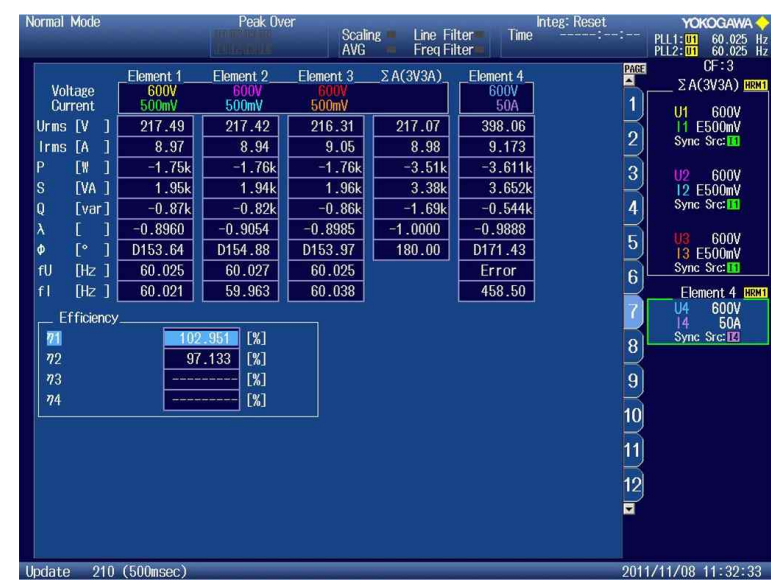

Fig. 22 System maximum efficiency

전모드 시 배터리 전압은 감소하게 되고, 방전 전력은 증가하게 된다. 방전 시 배터리 전압이 $3[\mathrm{~V}]$ 가 되면 더 이상의 동작은 수행하지 않고, 계속적으로 충전을 하게 된다.

\section{6. 결 론}

본 논문에서는 배터리 충-방전 테스트가 가능하며, 배터리 방전 시 계통으로 잉여 전력을 회생하여 주는 $15 \mathrm{~kW}$ 급 $\mathrm{AC}$ 회생 시스템을 제안하였다. 시뮬레이션을 통하여 계통의 위상각 검출 및 동상 및 역상의 전류를 확인하였다. 또한 데이터 모니터링 시스템을 개발하여 제안된 충-방전기의 각각의 모드에서 배터리 특성을 확인 할 수 있다.

본 논문은 중소기업청에서 지원하는 2011년도 산학 연협력 기업부설연구소 지원사업(No. 000438110211)의 연구수행으로 인한 결과물임을 밝힙니다.

\section{참 고 문 헌}

[1] Omar Hegazy iconManInfo, Joeri Van Mierlo, Philippe Lataire, "Control and Analysis of an Integrated Bidirectional DC-AC and DC-DC Converters for Plug-In Hybrid Electric Vehicle Applications", Journal of Power Electronics, Vol. 11, No. 4, pp. 408-417, 2011, July.

[2] Petr Kadurek, Christos Ioakimidis, Paulo Ferrao, "Electric Vehicles and their Impact to the Electric Grid in isolated systems", POWERENG, International Conference on, pp. 49-54, 2009, March.

[3] Marco Liserre, Frede Blaabjerg, Steffan Hansen, "Design and Control of an LCL-Filter-Based Three-Phase Active Rectifier", IEEE Transactions on, Vol. 41, No. 5, pp. 1281-1291, 2005, October.

[4] Jong-Pil Lee, Byung-Duk Min, Tae-Jin Kim, Dong-Wook Yoo, Ji-Yoon Yoo, "Active Frequency with a Positive Feedback Anti-Islanding Method Based on a Robust PLL Algorithm for Grid-Connected PV PCS”, Journal of Power Electronics, Vol. 11, No. 3, pp. 360-368, 2011, May.

[5] Karshenas H.R, "Basic Criteria in Designing LCL Filters for Grid Connected Converters", ISIE, IEEE International Symposium on, pp. 1996-2000, 2006, July.

[6] Hyeong-Su Kim, "PLL for Unbalanced Three-Phase Utility Voltage using Positive Sequence Voltage Observer", Journal of the Korean Institute of Power Electronics, Vol. 13, No. 2, pp. 145-151, 2008, April.

[7] Qingrong Zeng, Liuchen Chang, "An Advanced SVPWM-Based Predictive Current Controller for Three-Phase Inverters in Distributed Generation Systems", IEEE Transactions on, Vol. 55, No. 2, pp. 1235-1246, 2008, March.

[8] Zhang Guowei, Wei Tongzhen, Huang Shengli, Kong Lingzhi, "The control for grid connected inverter of distributed generation under unbalanced grid voltage", Sustainable Power Generation and Supply, 2009. SUPERGEN '09. International Conference on., pp. 1-5, 2009, April.

[9] Yun-Young Choi, Sang-Hoon Kim, "An Overmodulation Strategy for SVPWM Inverter", Power Electronics Annual Conference, pp. 135-138, 2000, November.

[10] Soo-Heum Lee, Young-Ho Bae, Jong-Soo Cho, Jong-Hyun Baek, "Analysis of a Three Phase PWM $\mathrm{AC} / \mathrm{DC}$ Converter With Input Current Waveform and Power Factor Correction", Journal of KIIEE, Vol. 12, No. 1, pp. 93-102, 1998, February. 

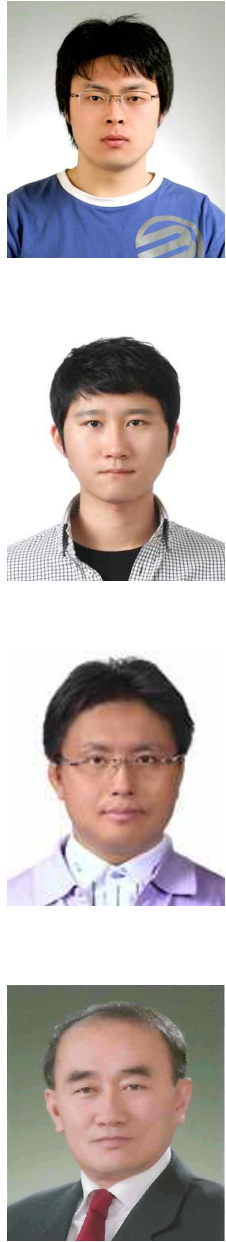

\section{원 충 연 (元忠淵)}

1955년 5월 10일생. 1978년 성균관대 공대 전기공학과 졸업. 1980년 서울대 공대 대학 원 전기공학과 졸업(공박). 1991년 12월 1992년 12월 미국 테네시 주립대학 전기공 학과 방문 교수. 1998년 현재 한국철도 기 술연구원 심사위원. 2006년 2009년 한국전력공사 PQ심사위원. 2006년 2009년 차세대 첨단도시철도시스템(한국건설교통기술 평가원) 기술개발사업 운영위원. 2006년 현재 (주)로템 기술자 문위원. 2010년 현재 도시철도 공사 기술검증위원. 2007년 현재 삼성전기 에너지파워 연구 센터장. 2011년 현재 한국토 지주택공사 기술심사 평가위원. 2010년 당 학회 회장. 현재 성 균관대 정보통신공학부 교수.

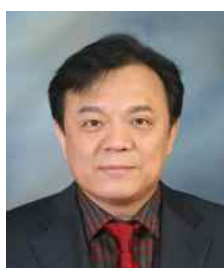

\section{나종국(羅種國)}

1959년 4월 24일생. 2006년 3월 24일 한국 산업기술대 전자공학과 졸업. 2012년 2월 한양대 대학원 전기공학과 졸업(석사). 1997 년 현재 (주) 갑진 대표이사. 